УДК 619:614.95:615.32:599.32

(C) 2013

Лясота В. П., доктор ветеринарних наук, професор

Сідніченко I. В., аспірант (науковий керівник - доктор ветеринарних наук, професор В. П. Лясота)

Білоцерківський національний аграрний університет

\title{
ДОКЛІНІЧНІ ДОСЛІДЖЕННЯ ВПЛИВУ ПРЕПАРАТУ «МІКОВІТАМ» НА ЛАБОРАТОРНИХ ЩУРАХ
}

\section{Рецензент - доктор ветеринарних наук А. А. Замазій}

\begin{abstract}
Викладені дані щзодо впливу «Міковітаму» на метаболізм білих щурів. Виявлено, щзо застосування у дозі 0,9 г Міковітаму сприяе зростанню вмісту гемоглобіну на 2,7\%, еритроцитів - 4,4\%, загального білка - на 2,4\%, а також зростанню маси білих щурів на 10,4\% порівняно з тваринами контрольної групи. Різниці в концентрації глюкози, загальних ліпідів, холестеролу, активності амінотрансфераз не встановлено. Для активації рівня природної резистентності, обмінних процесів, інтенсивності росту пропонується вивчати вплив біологічно активної сполуки як добавки до комбікорму сільськогосподарським тваринам.
\end{abstract}

Ключові слова: резистентність, білкововітамінна добавка, збереженість, корм, білі щури.

Постановка проблеми. В умовах посилення впливу на організм тварин негативних факторів, які призводять до зниження імунного статусу організму, порушення обміну речовин, виникнення різних захворювань, значно зростає доцільність використання природних біологічно активних речовин у профілактиці захворювань тварин. Впроваджуються у виробництво нові кормові добавки, одержані шляхом використання біотехнологічних прийомів, які містять комплекс незамінних амінокислот, вітамінів, макро- і мікроелементів, природних антиоксидантів, в тому числі атоксичних грибів та інших біологічно активних речовин. Ці заходи особливо важливі в умовах промислових технологій виробництва продукції птахівництва, що базуються на використанні сучасних висопродуктивних кросів птиці. Систематичне вживання птицею цих добавок дозволяс оптимізувати не тільки структуру раціонів годівлі, але й забезпечити одночасно профілактику захворювань птиці, підвищити якість та біологічну повноцінність продукції, що сприяє більш повнішій реалізації генетичного потенціалу продуктивності сучасних кросів. Збагачення комбікормів сільськогосподарської птиці екологічно безпечними, ефективними добавками дозволяє не тільки створювати продукти харчування із заданими властивостями, але й підвищити збереженість поголів'я і покращувати його відтворну здатність.
Аналіз джерел і публікацій, у яких започатковано вирішення даної проблеми. 31999 року в Україні діє наказ Державного департаменту ветеринарної медицини № 7 від 17.02.99 р. «Про посилення контролю за якістю і безпечністю ветеринарних препаратів і кормових добавок», який передбачає відтворення експериментальних методик аналізу на лабораторних тваринах, аналіз результатів експерименту й висновків щодо якості препарату та умов його застосування [1]. Вирішальний влив на виробництво продукції птахівництва має кормова база, iii рівень, якісний склад кормів та структура раціонів. Ефективно використовувати кормові запаси, забезпечувати тварин поживними й біологічно активними речовинами в кількостях і співвідношеннях, необхідних для одержання міцного життездатного приплоду, високої продуктивності й доброї якості продукції, можна лише за умов повноцінної і збалансованої годівлі [5]. Потреба у дослідженні крові визначається, передусім, іiі фізіологічним значенням і змінами, що настають за різних патологічних змін. У кров виділяються продукти життедіяльності різних органів, за вмістом яких можна визначити їх функціональний стан [2]. Доклінічні дослідження токсичності лікопінових препаратів із гриба Blakeslea trispora показали, що життєдіяльність, гематологічні, біохімічні показники були в межах норми без ознак токсичності.

Метою роботи було вивчення впливу біологічно активної сполуки «Міковітам» на збереженість, морфологічні, біохімічні показники крові білих щурів та інтенсивність росту їхньої маси тіла.

Для досягнення мети необхідно вирішити наступні завдання: а) проаналізувати вплив препарату «Міковітам» на збереженість та інтенсивність росту білих щурів; б) вивчити вплив «Міковітаму» на морфологічні показники крові білих щурів.

Матеріали і методи дослідження. Дослідний препарат перевіряли на білих щурах на базі віварію Білоцерківського НАУ, де тваринам були створені належні санітарно-гігієнічні умови утримання. В експерименті використовували біологічно активну сполуку «Міковітам», виготовлену на основі двох селекційних атоксигенних грибних штамів: Fusarium 


\section{ВЕТЕРИНАРНА МЕДИЦИНА}

sambucinum F-10011, Fusarium sambucinum F-139. Біологічно активна речовина складає специфічний комплекс фізіологічно-активних речовин. Препарат розроблений НДІ біохімії ім. Палладіна, а технологічно виготовлений на ПП «БТУ-центр» м. Ладижин Вінницької області. До складу препарату входить широкий спектр вітамінів із перевищенням тіаміну, пантотенової кислоти, нікотинової кислоти та іiі коферментна форма НАД. Препарат містить також значну кількість піридоксину, біотину, вітаміну Е, убіхінону (коензим $Q_{10}$ ), а також незамінні амінокислоти (лізин, триптофан, аргінін) і ненасиченні жирні кислоти (олеїнову, лінолеву, ліноленову, арахідонову). Вміст білка становить близько 41,3 \% [4].

Методи дослідження: зоогігієнічні (параметри мікроклімату) [Демчук М. В., 1994 р.], зоотехнічні, морфологічні (еритроцити, лейкоцити), біохімічні (гемоглобін, загальний білок, глюкоза, загальні ліпіди, холестерол, активність трансфераз) [В. І. Левченко, 2002 р.]. У крові білих щурів визначали вміст гемоглобіну - геміглобінціанідним методом, використовуючи тест-набір фірми «Сімко» ЛТД. Кількість еритроцитів і лейкоцитів підраховували в камері з сіткою Горяєва [2]. Загальний білок у сироватці крові визначали рефрактометром, глюкозу глюкозо-оксидазним методом, загальних ліпідів та активність амінотрансфераз - за допомогою реактивів фірми «Сімко»[3]. Для вивчення ефективності впливу препарату Міковітам на біологічні показники лабораторних тварин було сформовано три групи білих щурів по 5 у кожній із середньою масою тіла по 193-200 грамів. Перша група тварин, яка споживала основний раціон, була контрольною. Друга-третя групи лабораторних тварин були дослідними, яким з основним раціоном щоденно, пе- рорально, протягом 60 діб застосовували «Міковітам» iз розрахунку 0,36 та 0,9 г на 1 кг маси тіла у складі сухого корму - дробленого зерна (табл. 1). Водонапування не обмежене [5]. У цей час вели спостереження за клінічним станом, прийомом корму, води, захворюваністю, розмноження, інтенсивністю росту тварин. На 60-ту добу дослідження було проведено декапітацію і відбір крові 3 дотриманням санітарно-гігієнічних умов.

Результати досліджень. У результаті експерименту встановлено, що інтенсивність росту білих щурів дослідної групи зростала у динаміці й на кінець досліду (60-ї доби) становило 7,9-10,4 \%, порівняно 3 тваринами контрольної групи. Згідно 3 існуючою методикою, активним вважається препарат, якщо різниця між середньодобовими приростами маси тіла у групах становить не менше $10 \%$. Виявлено, що збереженість тварин як у дослідній, так і в контрольній групах становила 100 \%. Варто відмітити, що дослідні тварини добре вживали корм і воду. Поведінка дослідних тварин відповідала нормі (рухливі, активні) (табл. 2). Різниця у масі внутрішніх органів у дослідних і контрольних тварин (серце, печінка, селезінка) була незначною (табл. 3). Після вивчення впливу препарату «Міковітам» на показники крові білих щурів установлено активацію еритроцитопоезу, на що вказує збільшення у другій дослідній групі вмісту гемоглобіну на 2,7 \%, еритроцитів - на 4,4 \% (табл. 4). Під час вивчення впливу препарату «Міковітам» на біохімічні показники сироватки крові лабораторних щурів виявлено, що препарат підвищує вміст загального білка на 2,4 \%. Різниці в концентрації глюкози, загальних ліпідів, холестеролу, активності амінотрансфераз не встановлено (табл. 5).

\section{1. Схема застосування препарату «Міковітам» білим цурам}

\begin{tabular}{|c|c|c|c|c|}
\hline Показник & $\begin{array}{c}\text { Кількість } \\
\text { тварин, } \mathrm{n}\end{array}$ & $\begin{array}{c}\text { Доза, } \\
\text { Г/гол. }\end{array}$ & Кратність на добу & Тривалість, діб \\
\hline Дослід 1 & 5 & 0,36 & $\begin{array}{c}\text { основний раціон (подрібнене } \\
\text { зерно пшениці, комбікорм) }\end{array}$ & 60 \\
\hline Дослід 2 & 5 & 0,9 & $\begin{array}{c}\text { основний раціон (подрібнене } \\
\text { зерно пшениці, комбікорм) }\end{array}$ & 60 \\
\hline Контроль & 5 & - & $\begin{array}{c}\text { основний раціон (подрібнене } \\
\text { зерно пшениці, комбікорм) }\end{array}$ & 60 \\
\hline
\end{tabular}

2. Показники інтенсивності росту та збереженості білих цурів у разі застосування "Міковітаму» впродовж 60 діб $(M \pm m)$

\begin{tabular}{|l|c|c|c|}
\hline \multirow{2}{*}{ Показник } & \multicolumn{3}{|c|}{ Чере3 60 діб по закінченню досліду } \\
\cline { 2 - 4 } & контроль & дослід 1 & дослід 2 \\
\hline Кількість тварин у досліді, $\mathrm{n}$ & 5 & 5 & 5 \\
\hline Збереженість тварин, у \% & 100 & 100 & 100 \\
\hline Середня маса тіла тварин, г & $203,8 \pm 1,18$ & $220,0 \pm 1,54^{*}$ & $225,0 \pm 1,31^{* *}$ \\
\hline
\end{tabular}

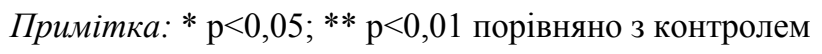


BETЕРИНАРНА МЕДИЦИНА

\section{3. Показники маси внутрішніх органів білих цурів після застосування "Міковітаму" протягом 60 діб (M $\pm m$, г)}

\begin{tabular}{|c|c|c|c|c|c|}
\hline Показник & $\begin{array}{c}\text { Кількість } \\
\text { тварин, } \\
\mathrm{n} \text { (гол.) }\end{array}$ & Серце & Печінка & Селезінка & Кишківник \\
\hline Контроль & 5 & $0,64 \pm 0,008$ & $6,19 \pm 0,04$ & $0,93 \pm 0,006$ & $7,45 \pm 0,03$ \\
\hline Дослід 1 & 5 & $0,72 \pm 0,005$ & $6,30 \pm 0,05$ & $0,96 \pm 0,007$ & $7,53 \pm 0,03$ \\
\hline Дослід 2 & 5 & $0,74 \pm 0,004$ & $6,35 \pm 0,04^{*}$ & $0,97 \pm 0,006$ & $7,60 \pm 0,03^{*}$ \\
\hline
\end{tabular}

Примітка: * $\mathrm{p}<0,05$

\section{4. Морфологічні показники крові білих щурів після застосування «Міковітаму»} через 60 діб $(M \pm m, n=5)$

\begin{tabular}{|l|c|c|c|}
\hline Показники, од. вимірювання & Контроль & Дослід 1 & Дослід 2 \\
\hline Еритроцити, Т/л & $6,8 \pm 0,03$ & $6,94 \pm 0,06$ & $7,10 \pm 0,05^{*}$ \\
\hline Лейкоцити, Г/л & $12,8 \pm 0,02$ & $12,8 \pm 0,03$ & $12,9 \pm 0,03$ \\
\hline
\end{tabular}

Примітка: * $p<0,05$

5. Біохімічні показники крові білих иурів після застосування «Міковітаму» через 60 діб $(M \pm m, n=5)$

\begin{tabular}{|l|c|c|c|}
\hline \multicolumn{1}{|c|}{ Показник, од. вимірювання } & Контроль & Дослід 1 & Дослід 2 \\
\hline Гемоглобін, г/л & $148,8 \pm 1,3$ & $149,6 \pm 1,9$ & $15,2 \pm 2,1^{*}$ \\
\hline Загальний білок, г/л & $70,7 \pm 0,37$ & $71,7 \pm 0,31$ & $72,4 \pm 0,34^{*}$ \\
\hline Глюкоза, мг/100 мл & $120,0 \pm 4,2$ & $120,6 \pm 4,0$ & $121,0 \pm 5,0$ \\
\hline Загальні ліпіди, мг/100 мл & $219,0 \pm 5,6$ & $220,0 \pm 6,4$ & $221,0 \pm 6,1$ \\
\hline Холестерол, мг/100 мл & $74,0 \pm 1,25$ & $74,4 \pm 1,37$ & $75,4 \pm 1,05$ \\
\hline Активність амінотрансфера3, & & & \\
ммоль/(год• л): & & & \\
АлАТ & $0,46 \pm 0,02$ & $0,47 \pm 0,02$ & $0,48 \pm 0,02$ \\
АсАТ & $0,90 \pm 0,04$ & $0,91 \pm 0,06$ & $0,92 \pm 0,08$ \\
\hline
\end{tabular}

Примітка: *p<0,05

\section{Висновки:}

1. За використання білково-вітамінної добавки «Міковітам» у дозі 0,9 г/гол. збереженість дослідних щурів становила $100 \%$. Інтенсивність росту маси тіла білих щурів за період досліду становила 10,4 \%, порівняно з контрольною групою. Згодовування препарату у дозі 0,9 г/гол. не викликало побічних явищ в організмі білих щурів.

2. Застосування препарату «Міковітам» сприяло помірній активації еритроцитопоезу в організмі білих щурів: підвищення вмісту гемоглобіну складало $2,7 \%$; еритроцитів $-4,4 \%$.

3. У разі задавання препарату «Міковітам» упродовж 60 діб спостерігається помірна активі-

\section{БІБЛІОГРАФІЯ}

1. Коиюмбас I. Я. Доклінічні дослідження ветеринарних лікарських засобів / І. Я. Коцюмбас. - Львів : Тріада плюс, 2006. - 360 с.

2. Левченко В. I. Дослідження крові тварин та клінічна інтерпретація отриманих результатів: Методичні рекомендації для студентів факульте- зація білкового обміну в організмі лабораторних білих щурів: незначне підвищення вмісту загального білка (на $2,4 \%$ ).

4. Різниці в концентрації глюкози, загальних ліпідів, холестеролу, активності амінотрансфераз не встановлено, що свідчить про те, що метаболізм в організмі білих щурів відбувається за рахунок анаболічних процесів.

Пропозиції виробництву. Для активації рівня природної резистентності, обмінних процесів, поліпшення збереженості, інтенсивності росту пропонується вивчати біологічно активну сполуку «Міковітам» методом перорального щодобового застосування як домішку до комбікорму.

ту ветеринарної медицини керівників та слухачів Інституту післядипломного навчання керівників і спеціалістів ветеринарної медицини / [В. І. Левченко, В. М. Соколюк, В. М. Безух [та ін.]. Біла Церква, 2002. - 56 с.

3. Левченко В. I. Біохімічні методи досліджен- 


\section{ВЕТЕРИНАРНА МЕДИЦИНА}

ня крові тварин: Методичні рекомендації для лікарів хіміко-токсикологічних відділів державних лабораторій ветеринарної медицини України, слухачів факультету підвищення кваліфікації та студентів факультету ветеринарної медицини / В. І. Левченко, Ю. М. Новожицька, В. В. Сахнюк [та ін.]. - К., 2004. - 104 с.

4. Патент України на корисну модель 90403. Спосіб одержання білково-вітамінного продукту на основі грибів Fusarium sambucinum IMF100011 i Micellia sterilia (white) IMB F-100014/
Г. В. Донченко, Ю. М., Пархоменко, С. М. Супрун [та ін.]. - Бюл. № $8 .-10$ c.

5. Проваторов $Г$. В. Норми годівлі, раціони і поживність кормів для різних сільськогосподарських тварин: довідник / [Г. В. Проваторов, В. І. Ладика, Л. В. Бондарчук; за заг. ред. В. О. Проваторова]. - 2-ге вид, стер. - Суми: Університетська книга, 2009. - 489 с.

6. Рохманов А. И. 99 советов. Декоративные крысы / А. И. Рохманов. - М. : Аквариум БУК, 2002. $-112 \mathrm{c}$. 